\title{
REFLEKSI HIBRIDITAS BUDAYA DALAM PANCASILA PADA REALITAS DAN MEDIA SEBAGAI IDENTITAS BANGSA
}

\author{
Rustono Farady Marta \\ Ilmu Komunikasi, Universitas Bunda Mulia \\ Alamat surel: rmarta@bundamulia.ac.id / rustonofarady@gmail.com
}

\begin{abstract}
Studies on the identity are being learned widely, mostly focus on specific groups. The reality we face today is shows the different conditions, because Indonesia has Pancasila as the state philosophy that clearly asserts the motto of "Bhinneka Tunggal Ika". Actually, the spirit that brought ethnic diversity want to be placed in a proper understanding in order to avoid inter-ethnic conflict. The thought has not been led to reform the nation's cultural identity because the implementation is still far from reality. Eddie Lembong (2013) created the 'Cross Culture Fertilization' concept or 'The Cross-fertilization of Culture' idea of Paul Monroe (1928), while the form of the pollination contemplated in the process of crosscultural thinking involves human interaction with a particular context. It needs to be enhanced by adopting the Rosenau's idea (2004) about the cultural hybridity in which the establishment of a culture based on the complexity of the dimensions of a person's life. The tangible implementation of cultural hybridity as a mirror of pluralistic nation identity exemplified through observation on the case studies and mass media of a national movie entitled "Tanda Tanya" ("Question Mark").
\end{abstract}

Keywords: Cultural hybridity, Pancasila, Reality and Media

\begin{abstract}
Abstrak
Studi mengenai identitas tengah marak dipelajari, sebagian besar kajian tersebut terpusat pada kelompok tertentu. Realitas yang kita hadapi dewasa ini justru memperlihatkan kondisi yang berbeda, karena Indonesia memiliki Pancasila sebagai dasar filosofi negara secara jelas menegaskan semboyan "Bhinneka Tunggal Ika". Semangat yang dibawa sebenarnya ingin mendudukkan keberagaman etnis dalam pemahaman yang tepat agar tidak terjadi konflik antar etnis. Pemikiran yang terjadi selama ini belum membuahkan reformasi budaya bangsa terhadap identitas, karena implementasinya masih jauh dari realitas. Eddie Lembong (2013) yang mencetuskan konsep cross culture fertilization, atau The CrossFertilization of Culture gagasan dari Paul Monroe (1928), sementara wujud proses penyerbukan yang dimaksudkan pada pemikiran proses silang budaya dengan melibatkan interaksi manusia pada konteks tertentu. Hal ini perlu disempurnakan dengan mengadopsi pemikiran Rosenau (2004) mengenai cultural hybridity, dimana pembentukan budaya didasarkan kompleksitas dimensi kehidupan seseorang. Lebih nyata implementasi hibriditas budaya sebagai cerminan identitas bangsa yang majemuk, dicontohkan melalui hasil observasi studi kasus dan media massa melalui film nasional berjudul "Tanda Tanya".
\end{abstract}

Kata kunci: Hibriditas Budaya, Pancasila, Realitas dan Media

\section{PENDAHULUAN}

Identitas menjadi perlambang suatu bangsa. Itulah yang menjadi rumusan utama lahirnya Pancasila yang diperingati setiap tahunnya jatuh pada tanggal satu bulan Juni. Ideologi yang menegaskan nilai-nilai keberagaman identitas agama, suku, bahasa, dan adat-istiadat daerahnya. Keberagaman tersebut membawa polemik tersendiri bagi bangsa ini, dimana slogan Bhinneka Tunggal Ika tidak mudah dipenuhi mengingat luasnya Negara Kesatuan Republik Indonesia.
Bagaimana komposisi etnis negara yang menempati urutan keempat di dunia ini dengan 201,24 juta jiwa jumlah penduduknya ini?

Studi ekonom-demografi, yaitu: Dr. Leo Suryadinata, Dr. Evi Nurvidya Arifin dan Dr. Anis Ananta menunjukkan komposisi dan perubahan etnis dan agama selama 3 tahun (1997-2000) terdapat 15 etnis yang paling dominan dari 1.128 etnis. ${ }^{1}$

1 Suryadinata, Leo, dkk. 2003. Indonesia's
Population: Ethnicity and Religion in a 
Tidak dapat terbantahkan bahwa diantara berbagai etnis dominan tersebut, terdapat tiga etnis yang paling banyak di Indonesia. Berturut-turut sesuai urutan jumlah terbanyak hingga paling sedikit, antara lain: Jawa $(83,86$ juta/41,71\%), Sunda $(30,97$ juta/15,41\%), Melayu (6,77 juta/3,37\%), sedangkan etnis yang menempati urutan terakhir adalah etnis Tionghoa $(1,73$ juta $/ 0,86 \%)^{2}$. Meski data tersebut masih bervariasi oleh beberapa sumber yang menyatakan jumlah etnis Tionghoa di Indonesia sebanyak tujuh juta, sembilan juta (voaindonesia) ${ }^{3}$ hingga 12 juta jiwa, namun hal yang pasti adalah etnis Tionghoa merupakan bagian dari penduduk Indonesia yang jumlahnya tidak dominan.

Tionghoa sebagai etnis minoritas seringkali memperoleh perlakukan diskriminasi, bahkan menjadi sasaran kerusuhan rasial. Semoga masih terbesit di benak kita, kerusuhan rasial di Jawa Barat 10 Mei 1963, penutupan sekolah-sekolah berbahasa Mandarin pada bulan Desember tahun 1966 dan berbagai surat kabar berbahasa Mandarin tahun berikutnya, pelarangan menggunakan aksara Mandarin di setiap produk atau media cetak di tahun 1979, hingga puncaknya peristiwa kerusuhan Mei 1998 yang banyak menyebabkan kerugian material, korban pemerkosaan, hingga pembantaian korban jiwa. Apa yang harus dilakukan agar konflik yang mengandung kerusuhan rasial ini tidak terjadi kembali? Terdapat dua arus utama yang harus ditempuh dari reformasi budaya bangsa ini, yaitu: penyerbukan silang antar budaya (fertilization of cross cultural identity) dan melestarikan berbagai alternatif

Changing Political Landscape. Jakarta: Pustaka LP3ES Indonesia.

2 Sesuai keterangan yang diberikan Rusman Heriawan selaku Kepala BPS (Badan Pusat Statistik) dalam Rapat Dengar Pendapat (RDP) dengan Komisi XI DPR RI, Rabu (03/02/2010)

3 http://www.voaindonesia.com/content/wargationghoa-indonesia-nikmati-kebebasanjalankan-tradisi-budayaleluhur/1601756.html. Diakses pada Hari Rabu, 20 Mei 2016 pk.10:46 WIB media konstruksi budaya (alternative media construction of culture).

\section{Konseptualisasi Cross Culture Fertilization}

Reformasi budaya bangsa dapat tercermin melalui pembentukan identitas. Indonesia dengan segenap kebhinnekaannya, sudah sepatutnya memiliki budaya yang menjadi modal sosial bangsa. Tentu saja modal tersebut tidak akan terwujud bila tercerai berai atau bahkan dijadikan sebagai sumber kerusuhan rasial, perlu adanya suatu bentuk komunikasi silang antar identitas budaya yang mumpuni. Hal ini dimaksudkan agar meredam pola etnosentris dan stereotip terhadap etnis budaya tertentu. Komunikasi silang antar budaya bukan berarti meleburkan identitas antar budaya yang dianut oleh etnis tertentu dengan etnis lain, seperti halnya istilah yang digunakan oleh Yayasan Nabil untuk penyerbukan silang antar budaya sebagai cross culture fertilization. ${ }^{4}$ Proses persilangan tersebut mencakup suatu bentuk adaptasi dari suatu identitas budaya seseorang dan/atau kelompok etnis tertentu terhadap identitas budaya lain yang dianggap mampu melengkapi identitas budaya yang sudah dimiliki, melekat, dan diwariskan oleh setiap generasinya.

Lebih jauh lagi, penyerbukan yang dimaksudkan agar identitas budaya dengan segenap perangkat budayanya mengadopsi identitas budaya lain tanpa menghilangkan sejatinya identitas budaya yang sudah ada. Proses penyerbukan silang antar budaya sangat dimungkinkan dalam proses pembentukan identitas, karena identitas dipandang sebagai citra diri reflektif yang dikonstruksi, dialami, dan dikomunikasikan oleh para individu dalam suatu budaya dan situasi tertentu. Hal ini pula yang digagas oleh Dr. Paul Monroe melalui tulisan yang berjudul "The Cross-Fertilization of Culture: The Function of International Education", dimana penerapan ide ini

4 Rukmana, Aan, Eddie Lembong. Makalah yang dibawakan dalam Kongres Kebudayaan Indonesia 2013 di Yogyakarta, 8 - 11 Oktober 2013 yang bertemakan: "Kebudayaan untuk Keindonesiaan." 
dilakukan untuk membantu pada pengajar pada The International Institute of Teachers College di Columbia University. Publikasi ilmiah yang dituangkan pada News Bulletin Institute of Pasific Relations (HonoluluHawaii, Februari 1928) ini, ditujukan unutk menjembatani perbedaan budaya antar pelajar dari berbagai negara. ${ }^{5}$

Pemikiran mengenai penyerbukan silang budaya tersebut melibatkan interaksi antara budaya dalam konteks tertentu yang mengkonstruksi identitas budaya tertentu, namun identitas budaya dapat berubah sesuai dengan bentukan lingkungan maupun lingkup pergaulan antar budaya yang mempengaruhinya. Hal ini sebenarnya telah dikonseptualisasi oleh ahli psikologi sosial, John Berry (1987) bersama Kim dan Boski pada tulisan yang berjudul Psychological Acculturation of Immigrants, ${ }^{6}$ diperkuat kembali oleh Berry di tahun 1992. Ia mengembangkan sebuah kerangka pemikiran yang mempertimbangkan hubungan antara migrants (pendatang) dan host (tuan rumah). Dalam konteks tulisan ini menyebutkan migrants sebagai pembawa budaya minoritas, sedangkan host menjadi budaya dominan. Perilaku mereka terhadap masing-masing budaya yang melekat dalam diri kedua pihak menghasilkan empat jenis hubungan yaitu: 1) assimilation, 2) separate, 3) integrate, dan 4) marginalized.
Assimilation adalah jenis adaptasi budaya dimana seorang individu melepaskan warisan budaya dengan sendirinya mengadopsi identitas budaya arus utama. Integration maupun separation adalah jenis adaptasi budaya dimana seorang individu mempertahankan budaya aslinya. Perbedaannya integration merupakan suatu kondisi dimana individu berinteraksi seharihari dengan kelompok lainnya, sementara separation dilakukan dengan jalan meminimalisir interaksi dengan kelompok lain. Marginalization adalah jenis adaptasi budaya yang menunjukkan kurangnya minat individu dalam mempertahankan ikatan budaya dengan budaya dominan maupun budaya migrants. ${ }^{7}$
5 Monroe, Paul. 1928. The Cross-Fertilization of Culture: The Function of International Education. News Bulletin (Institute of Pasific Relations), Pacific Affairs: University of British Columbia. Hlm.1-6

6 Jandt, Fred E.. 2007. An Introduction to Intercultural Communication: Identities in a Global Community $5^{\text {th }}$ Edition. California: SAGE Publication. HIm. 309 - 310
7 Neulip, James W. 2006. Intercultural Communication: A Contextual Approach $3^{\text {rd }}$ Edition. California: SAGE Publication. HIm. 420-421 
Tabel 1. Hubungan migrants dengan host (telah diolah dengan menggabungkan konsep penulis)

\begin{tabular}{|c|c|c|c|c|}
\hline $\begin{array}{l}\text { Klasifikasi } \\
\text { (John Berry, } \\
\text { 1992) }\end{array}$ & \multicolumn{2}{|c|}{$\begin{array}{l}\text { Migrantss Value Host/ } \\
\text { Majority Culture }\end{array}$} & \multicolumn{2}{|c|}{$\begin{array}{l}\text { Migrantss Devalue Host / } \\
\text { Majority Culture }\end{array}$} \\
\hline $\begin{array}{l}\text { Migrantss } \\
\text { Devalue Host/ } \\
\text { Minority } \\
\text { Culture }\end{array}$ & Assimilation & \multirow{2}{*}{\multicolumn{2}{|c|}{$\begin{array}{l}\text { Cultural Hybridity (Rosenau, 2004) } \\
>\text { Natural or given identity } \\
>\text { Unintentional identity } \\
\text { - Temporary identity } \\
\text { - Permanent identity } \\
>\text { Intentional identity } \\
\text { - Strengthen cultural identity } \\
\text { - Obscuring real - cultural identity } \\
>\text { Uninformity or by design identity } \\
\text { - Enrichment of cultural values } \\
\text { - Degradation of cultural values } \\
\text { Varieties in Culture Hybridity (Marta, } \\
\text { 2014) }\end{array}$}} & Marginalization \\
\hline $\begin{array}{l}\text { Migrantss } \\
\text { Value Host/ } \\
\text { Minority } \\
\text { Culture }\end{array}$ & Integration & & & Separation \\
\hline
\end{tabular}

Sumber: Martin dan Nakayama (2007:295)

Hubungan antara budaya minoritas dengan mayoritas dalam proses interaksi yang dapat diklasifikasi menjadi empat pola (simak Tabel.1). Ketika migrants menghargai warisan budaya mereka, maka timbul dua kemungkinan antara lain: assimilation atau integration. Assimilation terjadi bila mereka lebih menghargai budaya dominan daripada budaya mereka sendiri atau melakukan integration bila mereka menghargai keduanya. Ketika migrants menghargai budaya dominan maupun budaya warisan mereka, maka akan terjadi separation. Kondisi marginalized terjadi ketika migran kurang menghargai budaya dominan maupun budaya warisan mereka.

Rosenau (2004) menambahkan, bahwa sering kali para migrants melakukan kombinasi terhadap keempat jenis hubungan di atas berkaitan terhadap situasi sosial tempat dimana mereka tinggal. Para pendatang umumnya lebih menginginkan asimilasi ekonomi atau dalam bentuk riil diwujudkan melalui asimilasi di lingkungan pekerjaan, integrasi bahasa dengan bahasa setempat (bilingual), atau bahkan mereka melakukan pemisahan sosial dalam waktu yang bersamaan. Pemisahan ditempuh dengan cara menikahi seseorang yang berasal dari lingkungan sosial yang sama atau bergaul dengan mereka yang berada dalam satu kelompok. Hal itulah yang menyebabkan seseorang merasa bahwa dirinya tidak dengan mudah dikategorisasikan dalam empat jenis kerangka tersebut melainkan mereka masuk ke dalam varieties in culture hybridity yang merupakan produk campuran dari kedua atau lebih budaya. Dapat ditelisik lebih jauh bahwa penyerbukan dari dua atau lebih budaya akan membuat penambahan dan pengurangan budaya yang sudah ada, memungkinkan seseorang untuk memilih budaya mana yang akan dipertahankan dan dibuang. Oleh karena itu, sangat tidak mengherankan untuk kondisi saat ini jika seorang pendatang memiliki komposisi budaya yang berbeda satu dengan yang lainnya dimana anak menginginkan asimiliasi tetapi orang tua menginginkan integrasi. $^{8}$

\section{Realitas Hibriditas Budaya}

Dalam hal cultural hybridity, proses penyerbukan antar budaya dalam pembentukan identitas dapat dirumuskan lebih jauh lagi menjadi empat hal, yaitu:

\footnotetext{
8 Martin, Judith N., Thomas K. Nakayama. 2007. Intercultural Communication in Context $4^{\text {th }}$ Edition. New York, USA: McGraw Hill Hlm. 295-301
} 
identitas alami atau diberikan (natural or given identity), identitas secara tidak disengaja (unintentional identity), identitas yang diperoleh secara sengaja atas tujuan tertentu (intentional identity), dan identitas yang terjadi karena perilaku yang diseragamkan atau dipaksakan (uninformity or by design identity). Keempat hal tersebut merupakan refleksi pengamalan semboyan Pancasila sebagai landasan ideologi bangsa Indonesia, yaitu "Bhinneka Tunggal Ika".

Pertama, sedari awal manusia dilahirkan dalam lingkup keluarga pasti telah ditanamkan nilai-nilai budaya keluarga. Hal inilah yang disebut sebagai identitas budaya yang diperoleh secara alami atau diberikan (natural or given identity). Penyerbukan silang antar budaya berpeluang besar untuk terjadi dalam proses pembentukan identitas ini. Proses ini dapat berasal dari budaya yang dibawa oleh keluarga inti (pihak ibu dan ayah) atau diperoleh dari lingkup keluarga dekat yang berada di luar keluarga inti (paman, bibi, mertua, dll). Proses cross culture pollination yang berasal dari keluarga inti, baik dari pihak ayah maupun ibu umumnya akan terjadi pada individu yang telah beranjak remaja. Pada usia remaja mulai tumbuh kedewasaan untuk menentukan atau memilah perangkat terbaik untuk membentuk identitas budaya yang akan dianut.

Kedua, selama perkembangan hidup seseorang tinggal di suatu lingkungan yang secara tidak langsung dan berkesinambungan akan membentuk identitas budaya tertentu. Pada kurun waktu tertentu, lingkungan tersebut akan membawanya pada situasi dan kondisi yang secara tidak disengaja akan membentuk penyerbukan silang antar budaya yang membentuk identitasnya (unintentional identity). Identitas yang terbentuk dapat bersifat sementara (temporary identity) atau justru akan menjadi identitas budaya yang melekat dan menjadi corak kebiasaan (permanent identity). Pada umumnya individu yang cenderung tidak menetap dalam waktu yang lama, dan/atau tidak mengalami suatu pengalaman yang mendalam di suatu lingkungan tertentu, akan cenderung memiliki identitas yang bersifat sementara (temporary identity). Sebaliknya, identitas budaya yang melekat dan menjadi corak kebiasaan (permanent identity) terjadi bila seseorang menetap di lingkungan tertentu dalam waktu lama dan/atau lingkungan tersebut memberikan pengalaman yang mendalam.

Ketiga, sebagaimana tuntutan hidup setiap individu untuk senantiasa beradaptasi dengan lingkungan baru sebagai wadah aktualisasi diri. Entitas lingkungan baru terdiri dari individu dari berbagai latar belakang identitas budaya yang berbeda, sehingga besar peluang terjadinya penyerbukan silang antar budaya. Terdapat motif tertentu bagi setiap individu ketika beradaptasi dengan lingkungan pergaulan, salah satunya keinginan untuk diterima (acceptance) dan menjadi bagian dari komunitas tersebut. Pembentukan identitas budaya tersebut diperoleh secara sengaja didasarkan atas tujuan tertentu (intentional identity). Umumnya kondisi ini dapat berimplikasi pada dua kondisi, yaitu: memperkuat identitas budaya yang sudah dimiliki (strengthen cultural identity) atau justru mengaburkan identitas budaya asli atau sejatinya (obscuring real-cultural identity)

Keempat, pada hakekatnya manusia harus tunduk pada aturan yang berlaku dalam suatu institusi masyarakat tempatnya bernaung, entah berupa lembaga formal maupun organisasi non-formal. Institusi tersebut memiliki identitas budaya yang memaksa individu untuk berperilaku sebagaimana yang diseragamkan (uniformity or by design identity). Nilai budaya yang ditanamkan institusi dapat berimplikasi pada dua kondisi, yaitu: memperkaya nilai-nilai budaya (enrichment of cultural values) atau justru mendegradasi berbagai nilai budaya yang dimilikinya (degradation of cultural values).

\section{Pembelajaran Kasus Hibriditas Budaya}

Bila ditelisik dari contoh nyata yang dapat digunakan sebagai ilustrasi, MK (23 tahun) dan LA (25 tahun), putra kedua dan putri pertama yang lahir dari ayah peranakan Tionghoa asal Provinsi Bangka Belitung, kemudian menikah dengan ibu yang berasal dari etnis Jawa Tengah. Sang ayah menganut 
agama Konghucu, sementara ibunya adalah seorang muslim, kemudian LA bertindak sebagai anak sulung (kakak MK) juga seorang muslimah. Berbagai perbedaan yang dialami keluarga MK dan LA, namun mereka tetap memegang teguh prinsip Tuhan yang Esa sehingga keberagaman dalam suatu lembaga terkecil ini dapat terjaga utuh dan terus menerus dipupuk atas dasar cinta kasih kemanusiaan mengatasi segala ragam perbedaan. Kondisi ini mencerminkan sila pertama dan kedua Pancasila yang berbunyi "Ketuhanan Yang Maha Esa" serta "Kemanusiaan yang adil dan beradab".

Hal ini pula yang terjadi pada MK yang dibesarkan di kota Jakarta Utara, namun seringkali diajak ibunya kembali ke Jawa Tengah dan ayahnya pun tak jarang mengajaknya pula pulang ke kampung halaman di Pulau Belitung. Hal ini terutama di saat perayaan besar tradisi keluarga Tionghoa. Ketika MK berhadapan dengan keluarga dari pihak Ayah, baik di Jakarta maupun di Belitung, meski tak fasih berbahasa Hakka namun secara pasif Ia mampu memahami dialek khasnya. Kebiasaan yang tak pernah lepas bahkan seakan-akan menjadi ritual wajib bagi MK di setiap bulan ketika tidak ada hari kuliah tatap muka, yaitu berkunjung ke sanak famili yang berasal dari pihak ibunya. Keluarga tersebut sebagian besar menetap di sepanjang pesisir selatan Provinsi Jawa Tengah (Prembun, Cilacap, Wonosobo, dst), sehingga tak mengherankan bila MK sangat fasih bertutur kata dan berdialek khas Jawa.

Identitas budaya awal MK yang dilahirkan dalam lingkup keluarga Tionghoa Hakka dan Jawa Tengah, telah ditanamkan nilai-nilai budaya yang diperoleh secara natural or given identity. Seiring pendewasaan usia MK, maka pola penyerbukan silang antar budaya melalui hibriditas budaya yang terbentuk pada tahapan unintentional identity telah berlangsung dalam dua proses sekaligus, secara temporary identity maupun permanent identity. Pola temporary identity terbentuk ketika MK berinteraksi dengan budaya Tionghoa Hakka, ditunjukkan melalui kemampuan bahasa sebagai wujud elemen budaya yang dipahami MK secara pasif. Di sisi lain permanent identity juga terjadi saat budaya Jawa Tengah dipahami dan terbentuk melalui bahasa yang digunakan sehari-hari. Hal ini dapat terjadi, karena MK sebagai individu yang tumbuh serta memperoleh pengalaman secara mendalam di dua lingkungan identitas budaya sekaligus.

MK terbiasa memiliki kegigihan dalam membantu pekerjaan ayahnya sembari meniru kebiasaan akrab bersosialisasi dengan berbagai lapisan masyarakat sebagaimana ajaran ibunya. Pertautan budaya yang diadaptasi oleh MK mencerminkan usaha persatuan bangsa yang dipertemukan dalam satu insan, sebagaimana sila ketiga Pancasila yang berbunyi "Persatuan Indonesia".

Berbeda dengan agama yang dianut kedua orang tua MK, dimana agama Kristen menjadi pilihan menyandarkan imannya. Berawal dari gereja yang dipilih untuk beribadah adalah Gereja Kristus Yesus (GKY), karena mengikuti kakak perempuannya. Padahal saat LA (kakak MK) beribadat di GKY, hanya dikarenakan alasan mengikuti teman-teman sebayanya saja. Kini seiring dengan berjalannya waktu, ketika sang kakak memutuskan untuk mengikuti jejak ibunya sebagai muslim, maka MK pun pindah ke Gereja Bethel Indonesia (GBI) tempat dimana temanteman kuliahnya banyak beribadah. Pilihan LA untuk mengikuti nilai-nilai budaya Jawa yang diturunkan keluarga ibunya, juga sebagai upaya agar lebih dekat pada temanteman tetangga rumah yang beribadah di mesjid terdekat serta saudara-saudara sepupunya di Jawa Tengah yang mayoritas menganut ajaran agama Islam. Identitas budaya personal cenderung disesuaikan dengan identitas budaya yang dianut lingkungan sekitarnya, hal ini terbukti dari perpindahan LA sebagai mualaf dan MK menjadi kristen Bethel.

Motif MK maupun LA ketika beradaptasi dengan lingkungan pergaulannya agar diterima dan menjadi bagian dari komunitas tertentu. Pembentukan identitas budaya diperoleh secara sengaja didasarkan atas tujuan tertentu atau terbentuk melalui intentional identity. Realitas pembentukan identitas 
budaya MK dan LA menggambarkan proses penyerbukan silang antar budaya diperoleh secara tidak sengaja dari lingkungan pergaulan berbaur dengan identitas budaya yang dibawa dari keluarga. Bentuk intentional identity yang terjadi pada MK dan LA berbeda, keputusan LA untuk menjadi mualaf cenderung memberi dampak pada strengthen cultural identity dengan meneruskan agama islam yang dianut keluarga dari pihak ibu di Jawa Tengah. Di sisi lain, MK justru mengaburkan identitas budaya atau pola obscuring real-cultural identity melalui keputusan memilih agama Kristen , tidak meneruskan Konghucu yang dianut oleh sang ayah maupun sebagai muslim seperti sang ibu. Keputusan bijak yang diambil oleh MK merupakan jalan tengah yang tidak memihak kepada ayah maupun ibu, bila ditarik lebih jauh maka sikap ini mencerminkan sila keempat Pancasila yang berbunyi "Kerakyatan yang dipimpin oleh hikmat kebijaksanaan dalam perwakilan".

Saat MK duduk di bangku SMA negeri di bilangan petak sembilan, yang dahulu dikenal sebagai Tiong Hoa Hwe Koan dan SMP swasta di daerah Jakarta Barat. Selain lokasinya berada dalam kawasan yang kental dengan budaya oriental di bilangan Jelambar-Jakarta Barat, sekolah ini juga memiliki murid yang mayoritas berasal dari etnis Tionghoa serta perantauan asal Pulau Sumatera yang beragama Buddha atau Konghucu. Sebagian besar murid sekolah tersebut tidak memiliki referensi berbahasa Jawa. MK mempelajari identitas budaya, cara bertutur kata serta dialek bahasa Fujian atau yang umumnya disebut bahasa Hokkien sederhana. Salah satu contoh dalam keseharian seperti ungkapan: chincai, ceban, cepek, dst. Tanpa disadari pula bahwa dialek bahasa Jawa yang MK miliki tidak dapat dipertukarkan dengan teman sebayanya. Kondisi yang jauh berbeda saat bergaul dengan teman-teman di sebuah kampus swasta di bilangan Jakarta Utara, tempat MK menempuh pendidikan tinggi. Tampak kebiasaan serta dialek khas kekinian Jakarta bercampur Tionghoa digunakan sebagai percakapan sehari-hari sekaligus syarat untuk diterima dalam pergaulannya, seperti ungkapan: loe, gua, dst. Selain itu, terdapat beberapa dosen yang fasih bertutur kata dengan bahasa dan dialek Jawa di kampus, sehingga MK terbiasa mempertahankan nilai-nilai budaya Jawa.

Situasi pertautan budaya hingga munculnya dialek-dialek khas ini sebagai bukti aset kekayaan budaya lokal, yang mana sarat akan nilai-nilai budaya Jakarta dan telah terakulturasi dengan TionghoaFujian. Proses uninformity atau by design identity ini terbentuk berdasarkan pola enrichment of cultural values, karena identitas budaya asal yang dimiliki oleh MK menjadi berkembang oleh proses melembaganya dialek Jawa. Di sisi lain, ketika masa kecil di bangku sekolah MK dihadapkan pada anggapan umum, yang memperlihatkan orang dengan berbahasa daerah dianggap kampungan atau tidak moderen. Hal ini juga diperparah oleh latar belakang teman akrab belajar yang tidak satupun berasal dari etnis Jawa, sehingga hal ini yang menjadi alasan utama MK tidak bertutur kata dalam bahasa Jawa selama studi sekolah menengah. Cara MK ini dapat digolongkan ke dalam degradation of cultural values, meskipun budaya Jawa di benaknya tetap terpelihara berkat kedekatan dengan Ibu beserta kerabatnya di Jawa Tengah. Pola mengadaptasi lingkungan sekitar yang dialami MK, disiasatinya agar tidak menyebabkan kesenjangan sosial dengan memegang teguh prinsip sila kelima Pancasila yang berbunyi "Keadilan sosial bagi seluruh rakyat Indonesia".

\section{Hibriditas Budaya dalam Media Massa}

Pada penelitian yang pernah dilakukan sebelumnya pada film Tanda (?) Tanya (Marta, 2014) dimana penjabaran studi menggunakan analisis wacana kritis Teun A Van Djik untuk menganalisis datadata seperti teks pada film terhadap dominasi kelompok mayoritas etnis dan agama dalam membungkam minoritas dalam teks media massa sebagai fokus penelitian. Analisis dimulai dari struktur mikro, kemudian superstruktur, struktur makro, kognisi sosial, dan analisis sosial.

Struktur mikro kelompok minoritas memperlihatkan bahwa latar yang diangkat dari kisah minoritas etnis Tionghoa adalah lika-liku kehidupan antara etnis dan umat 
beragama yang berbeda dalam menjalani kehidupannya, melalui proses yang tidak mudah. Perjalanan hidup yang menceritakan kelompok minoritas bertahan di tengah "aturan normatif" kelompok mayoritas. Dimulai dari tiga keluarga yang tinggal di sebuah desa Kota Semarang, Jawa Tengah: keluarga Tionghoa-Indonesia dan beragama Konghucu, Tan Kat Sun dan anaknya Hendra. Selain itu, pasangan muslim yang bernama Soleh dan Menuk, lalu Rika yang beragama Katolik dan Abi anaknya memeluk agama Islam, dimana keduanya beretnis Jawa.

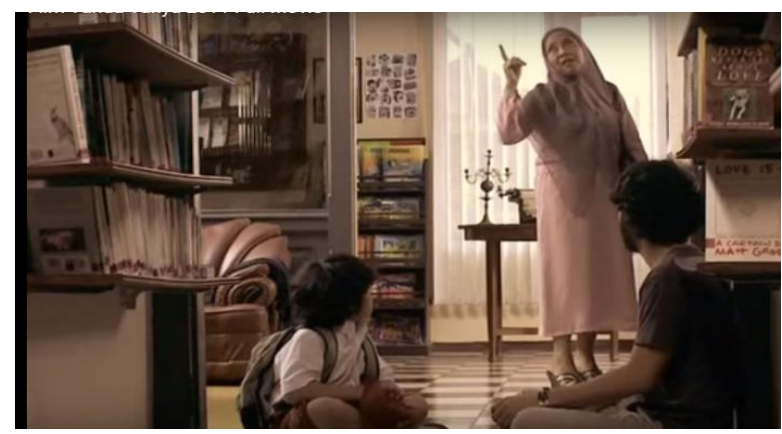

Sumber: Diambil dari unit analisis riset analisis wacana film (Marta, 2015)

Gambar 1. Film Tanda Tanya scene 26:57

Konstruksi budaya dan agama yang dilakoni oleh tiga keluarga tersebut banyak menuai perdebatan pada awalnya, karena mereka ini masih nyaman hidup dengan natural or given identity sebagai entitas asal mereka. Di sisi lain, ada anggota keluarga yang mendukung kegiatan bersosialisasi dengan agama dan etnis lainnya, namun sebagian lainnya justru berlaku sebaliknya. Hal ini dapat diketemukan pada kelompok mayoritas muslim yang menentang keras minoritas di dalam dialog yang diutarakan oleh seorang ibu kos ketika mendatangi perpustakaan yang dikelola Rika. Saat itu Rika sedang berada di luar rumah, sementara hanya terdapat Surya dan Abi yang tetap tinggal.

Ibu Novi (Bu Kos berjilbab) pada gambar 1. berkata, "Saya mau pesan sama kamu nanti kalau pacar kamu itu pulang bilang ya kalau toko buku ini mau laku mbo menjual buku-buku agama Islam, pasti laris. Nanti tak hubungkan sama penerbitnya, kebetulan suamiku itu menerbitkan bukubuku agama Islam. Nah untuk kamu Bi, kamu bisa pilih banyak komik-komik Islam yang lebih bagus. Mau gak kamu membacanya? Biar pintar tidak seperti ....", sambil menunjuk ke arah Surya.

Pada adegan tersebut nampak jelas bahwa Ibu Novi mencoba memperkuat legitimasi agama sebagai bentuk strengthen cultural identity melalui anjurannya, yakni menyarankan unutk menjual buku-buku agama islam. Di sisi lain, Surya yang beragama muslim pula tidak melakukan hal yang sama, dimana pola obscuring real cultural identity ditempuh dengan tidak memaksakan ajaran agama yang dipeluknya sebagai bahan bacaan yang dijual. Kondisi ini justru memudahkan Abi mempelajari agama Islam secara jernih, kemudian taat menjalaninya sebagai permanent idenitty.

Hal tersebut mendukung gambaran dari teori oleh Hecht tentang Communication Theory of Identity yang menyatakan bahwa kelompok pendatang (minoritas) akan mengalami 'jenjang identitas' di wilayah kelompok mayoritas. Kesenjangan dari identitas masyarakat yang homogen dengan identitas kelompok tertentu, sehingga menciptakan hirarki yang tersegmentasi. Identitas juga seringkali didefinisikan dalam term kewarganegaraan, ras, dan etnis. ${ }^{9}$ Dalam film ini identitas yang dimaksud adalah kesenjangan antar kelompok yang berbeda etnis maupun

\footnotetext{
9 Littlejohn. Stephen W. 2009. Enclycopedia of Communication Theory. USA: SAGE Publication Hlm. 140-141
} 
agama. Superstruktur kelompok minoritas pada film " Tanda Tanya", peneliti menjelaskan cerita tiga keluarga berbeda etnis dan agama secara skematik atau dipetakan berdasarkan empat tahap, mulai dari skema I, skema II, skema III, dan skema IV.

Tiga keluarga yang saling memiliki pro dan kontra dari internal anggotanya (personal), sehingga membentuk perbedaan yang ada.

Etnis dan agama minoritas yang terbungkam, karena adanya 'aturan normatif' kelompok mayoritas yang harus dipatuhi dan/atau dijalani oleh minoritas.

Beberapa personal di dalam tiga keluarga yang berusaha menumbuhkan harmonisasi agar meredam dominasi 'aturan normatif' kelompok mayoritas.

\section{$+$}

Pencarian jati diri personal untuk membangun relasional yang harmonis di tingkat komunal umat beragama maupun berbeda etnis, baik inisiatif yang muncul dari bagian kelompok mayoritas maupun minoritas.

Sumber: Diambil dari skema riset analisis wacana film (Marta, 2015)

Gambar 2. Skematik Superstruktur

Skematik pertama dapat dilihat ketiga keluarga, yaitu Tan Kat Sun yang beretnis Tionghoa dan beragama Konghucu. Setelah itu pasangan Muslim, Soleh dan Menuk yang sudah memiliki dua anak. Terakhir seorang ibu dan anak beretnis etnis Jawa dengan ibu yang beragama Katolik dan anaknya yang seorang Muslim. Masingmasing keluarga tersebut menunjukkan natural or given identity. Di sisi lain pada salah satu keluarga, terdapat pribadi yang kontra, yakni Hendra dari keluarga Tionghoa yang menentang bahwa ia dan keluarganya harus mengikuti 'aturan normatif' kehidupan kelompok mayoritas. Pada gambar 3. tampak Hendra menentang perintah ayahnya, yakni memerintahkan karyawannya menarik kain yang menutupi rumah makannya selama bulan puasa.

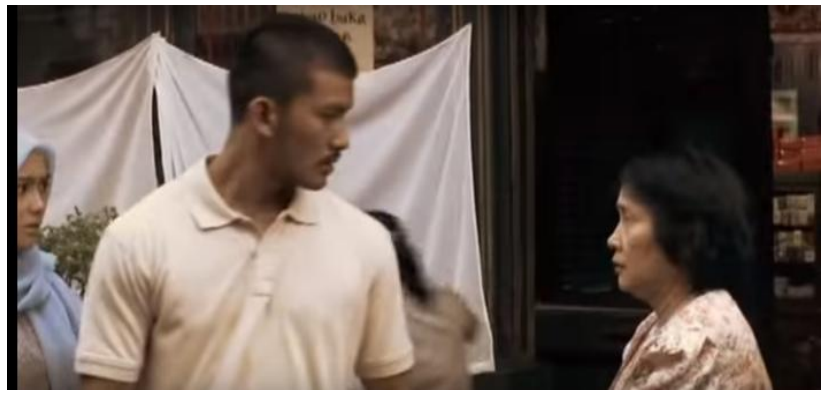

Sumber: diambil dari unit analisis riset analisis wacana film (Marta, 2015)

Gambar 3. Film Tanda Tanya Scene 1:02:48 
Pada suatu ketika, Hendra kembali bertindak melawan 'aturan normatif' dengan tidak mendengarkan ajaran untuk memisahkan peralatan masak antara daging babi dengan daging yang dihalalkan hingga dilarang menjual daging babi selama bulan puasa oleh Tan Kat Sun. Selain itu, Ia pun membuka rumah makan di hari raya Idul Fitri, sehingga menuai konflik berupa pandangan buruk dan tindak anarkis dari kelompok mayoritas. Sang ayah pun sudah melarang hal tersebut, namun tetap dilawan pula oleh Hendra. Hal ini sangatlah bertentangan dengan pentingnya menghormati rasa kemanusiaan, sepertinya yang tertuang pada sila kedua Pancasila yang berbunyi "Kemanusiaan yang adil dan beradab".

Tindakan Hendra tampak sebagai wujud degradation of cultural values, karena perilaku toleransi serta kepekaan sosial yang selama ini dikerjakan oleh Tan Kat Sun menunjukkan adanya usaha menciptakan keharmonisan. Sesuai dengan teori yang dikembangkan oleh Guo-Ming Chen pada Chinese Harmony Theory. Harmonisasi menjadi hasil akhir dari komunikasi Jen-Yi$\mathrm{Li}$ dimana teori tersebut mengambil unsur Yin dan Yang sebagai kunci keharmonisan yang bertolak belakang tetapi saling melengkapi. ${ }^{10}$

Belum lama setelah perilaku egoisnya, toko yang selama ini dirintis oleh sang ayah mendadak diserang massa tak dikenal, seketika Hendra mendapati Tan Kat Sun jatuh tersungkur setelah memperoleh pukulan benda tumpul. Kondisi ini menyebabkan timbulnya penyesalan dan kesedihan dalam hati Hendra, ketika mendapati ayahanda meninggal di hadapannya.

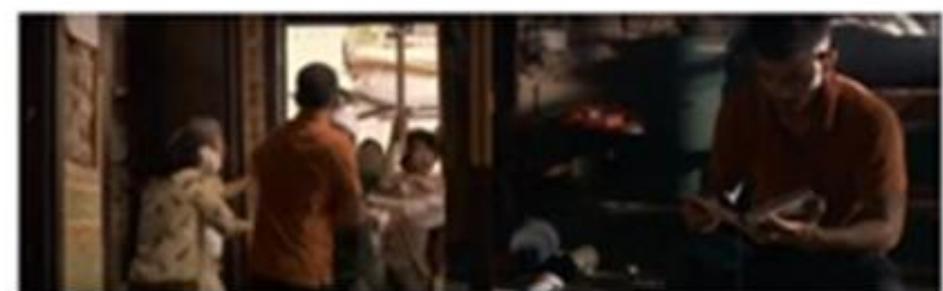

Sumber: diambil dari unit analisis riset analisis wacana film (Marta, 2015)

Gambar 4. Film Tanda Tanya scene 1:18:57 (kiri) dan scene 1:41:39 (kanan)

10 Ibid., et.al., Hlm. 95-96 
Di kala Hendra tertimpa masalah, Ia menemukan suatu buku yang berjudul ' 99 Asmaul Husna' (gambar 4.4) hingga akhirnya membuka hatinya, kemudian berpindah ke agama Islam. Pilihan Hendra tersebut selaku etnis Tionghoa yang aslinya beragama Konghucu menunjukkan bentuk obscuring real - cultural identity, kemudian diperkuat dengan alur cerita yang digiring pada suatu kondisi bahwa keterpurukan hidup keluarga Hendra berujung pada keputusannya menjadi mualaf. Kondisi penyerangan toko hingga alur cerita yang menggiring tokoh ini cenderung berkontradiksi dengan upaya mempersatukan perbedaan antar umat manusia, tercermin melalui pengamalan sila ketiga yang berbunyi "Persatuan Indonesia".

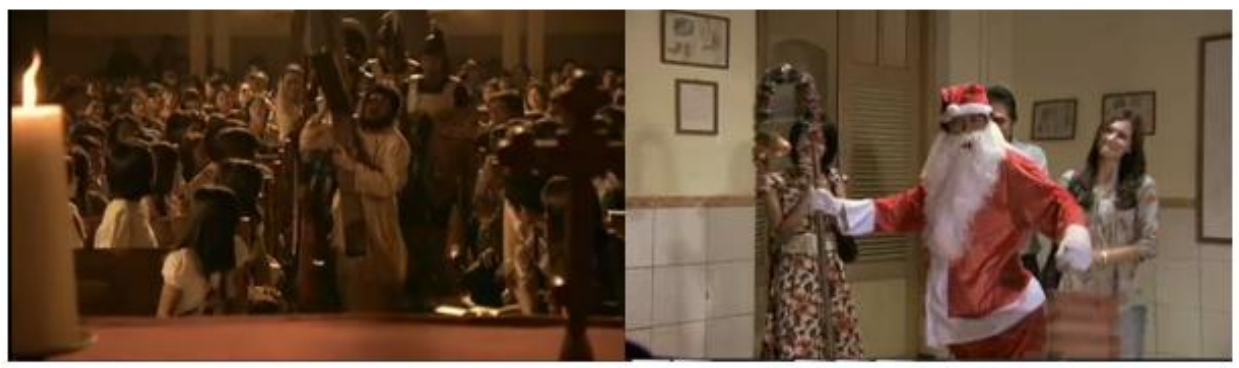

Sumber: diambil dari unit analisis riset analisis wacana film (Marta, 2015)

Gambar 5. Film Tanda Tanya scene 0:55:07 (kiri) dan scene 1:07:45 (kanan)

Berbagai unsur kemajemukan bangsa seakan ingin dilebur menjadi satu dengan agama yang dianut oleh kelompok mayoritas, sementara agama yang dianut kelompok minoritas dibungkam dengan cara kontak fisik hingga yang paling halus sekalipun. Terdapat upaya pembungkaman melalui dominasi mayoritas agama terhadap kelompok minoritas, sejalan dengan penjelasan muted group theory yang diungkapkan oleh Kramarae, dimana kelompok minoritas akan memperoleh perlakuan oleh kelompok dominan. ${ }^{11}$

Surya pada gambar 4.5 selaku etnis Jawa-Muslim yang selama ini berperan sebagai Santa Claus maupun Yesus dalam pementasan drama di saat Paskah dan Natal gereja merupakan bagian dari harmonisasi dari bagian kelompok mayoritas. Kebaikan yang dilakukan oleh Surya mampu membuka khasanah berpikir yang lebih luas, dengan melihat perbedaan agama dari pola

11 Griffin, Em, 2015. A First Look at Communication Theory Ninth Edition. Singapore: McGraw-Hill International Edition. Hlm. 457-465 enrichment of cultural values. Berbagai nilai budaya dirasakan secara seksama untuk memuliakan Tuhan yang Esa, sebagaimana bunyi sila pertama. Di sisi cerita lain terdapat keluarga Menuk dan Soleh yang mempunyai perbedaan pendapat, karena Menuk bekerja di rumah makan ayah Hendra berusaha mendekonstruksi pemikiran konvensional setelah melihat sendiri upaya membangun toleransi mulai dari hal yang terkecil. Upaya obscuring real - cultural identity ini justru ditentang oleh suaminya, karena merasa tidak nyaman dengan hal tersebut. Hal yang membuat Ia semakin geram adalah natural or given identity sebagai entitas yang melekat pada Soleh beretnis Jawa-Islam cenderung tidak menyukai Hendra dari etnis TionghoaKonghucu.

Persepsi negatif Soleh ini makin diperparah oleh pengalaman kisah cinta beda agama di masa lalu, antara Hendra dengan Menuk. Situasi memanas antara Hendra, Menuk dan Soleh tidak berlangsung lama, suatu ketika Soleh memperoleh pekerjaan baru, yaitu bertugas sebagai Banser NU (Barisan Ansor Serbaguna Nahdatul Ulama) yang menjaga keamanan di sekitar gereja 
Katolik. Pada awal masa kerjanya di akhir tahun, bertepatan dengan momen perayaan hari raya Natal umat Kristiani. Pekerjaan ini justru menjadi malapetaka bagi Soleh, ketika Ia menemukan bom di dalam gereja yang dibawanya pergi menjauh agar tidak meledak untuk memakan korban berjatuhan melainkan merenggut nyawanya. Pengorbanan Soleh ini mengakar pada kematangan berpikir secara bijak, sebagaimana pengamalan sila keempat Pancasila. Di sisi lain terdapat sikap dasar harmonis yang dibangun sang istri dengan umat beda agama dan etnis lain atas ajaran almarhum Tan Kat Sun. Tanpa memandang asal usul etnis maupun agama sebagai entitas budaya yang melekat, melainkan beroleh sikap adil sesuai sila kelima Pancasila.

\section{PENUTUP \& SIMPULAN}

Prinsip cross culture fertilization melalui pola varieties in culture hibridity (Marta, 2014 \& Rosenau 2004) sebagai refleksi nilai Pancasila merupakan keunggulan entitas budaya bangsa Indonesia. Betapa tidak, bila kerangka pikir ini dapat disemaikan oleh segenap warga negara ini, maka terjadi toleransi serta tepa selira antar agama, suku, bahasa, dan adatistiadat antara satu sama lain akan memandang sederajat (tanpa ada yang merasa lebih mayoritas atau bahkan minoritas). Lebih jauh lagi jika ditinjau dari landasan filosofisnya, hal ini telah dituangkan dalam Pancasila. Kondisi yang sedemikian ideal akan menjaga keharmonisan hidup berbangsa dan bernegara di masyarakat, sehingga terhindar dari tindakan chaos atau kerusuhan massa. Situasi ini telah didambakan oleh para founding fathers bangsa yang menetapkan semboyan Pancasila yang berbunyi: "Bhinneka Tunggal Ika".

\section{DAFTAR PUSTAKA}

Griffin, Em, 2015. A First Look at Communication Theory Ninth Edition. Singapore: McGraw-Hill International Edition.

Jandt, Fred Edmund. 2007. An Introduction to Intercultural Communication: Identities in a Global Community $5^{\text {th }}$ Edition. California: SAGE Publication. Hlm. 309 - 310

Littlejohn, Stephen W. and Karen A. Foss. 2008. Theories of Human Communication Ninth Edition. USA: Thomas Wadsworth

Littlejohn. Stephen W. and Karen A. Foss. 2009. Enclycopedia of Communication Theory. USA: SAGE Publication

Martin, Judith N., Thomas K. Nakayama. 2007. Intercultural Communication in Context $4^{\text {th }}$ Edition. New York, USA: McGraw Hill.

Moleong, J Lexy. 2010. Metode Penelitian Kualitatif, Bandung: Remaja Rosadakarya.

Neulip, James W. 2006. Intercultural Communication: A Contextual Approach $3^{\text {rd }}$ Edition. California: Sage Publication.

Rukmana, Aan, Eddie Lembong. 2013. "Kongres Kebudayaan Indonesia 2013" dalam Makalah "Kebudayaan untuk Keindonesiaan". Yogyakarta: Yayasan Nabil.

Rusman Heriawan. Februari 2010. "Indonesia Memiliki 1.128 Suku Bangsa" pada http://www.jpnn.com/index.php?id=5 7455\&mib=berita.detail. (Diakses pada Hari Rabu, 20 Mei 2014 pk.10:45 WIB

Suryadinata, Leo, dkk. 2003. "Indonesia's Population: Ethnicity and Religion in a Changing Political Landscape" pada

http://www.voaindonesia.com/conten t/warga-tionghoa-indonesia-nikmatikebebasan-jalankan-tradisi-budayaleluhur/1601756.html. Jakarta: Pustaka LP3ES Indonesia. (Diakses pada Hari Rabu, 20 Mei 2014 pk.13:45 WIB) 